\title{
Causes of Child Adoption in Taiwan, 1906-1940: The Importance of Gender, Household Composition and Variation over Time and Place
}

Tim Riswick \& Xingchen ChiaChi Lin

\begin{abstract}
Adoption has been an important historical Eastern Asian family strategy to ensure family continuity. Adopting children out of the household can, however, also be seen as a strategy for dealing with excess children. This topic is the focus of our article, which investigates who was given away for adoption and why in Taiwan during the period 1906-1940. The Taiwan Historical Household Register Database (THHRD), which can take changing household composition over time into account, is analysed using univariate and Cox proportional-hazard analyses. Results demonstrate that gender, birth position among siblings of the same sex, and variation across place and time are the most important factors explaining the likelihood of being adopted for all children. Socio-economic position also played an important role and the presence of a grandfather and grandmother lowered the likelihood of being adopted especially for boys, while only the presence of a grandmother had the same effect for girls. Moreover, when looking more specifically at adoption risks for girls, the age, gender and adoption status of siblings in the household seem to matter as well, as similarly aged young siblings of either sex increased the likelihood of being adopted for girls. These findings underscore that household decision making regarding adoption is more complex than simply giving away later-born children and that it is important to also pay more attention to the reasons and motivation of households in giving away children for adoption. It provides a broader perspective on adoption practices and how children were circulated from households with too many to those with too few and how this benefitted both kinds.
\end{abstract}

Key words: Adoption; Birth Order; Chinese Family; little daughter-in-law; Taiwan 


\section{Introduction}

For many centuries, securing descent and the family line has been an important element of Eastern Asian family strategies because it was central to the definition of the family. Only sons could perform this function of 'social reproduction' for the family, causing women to be needed only for 'biological reproduction' (Chu and Yu 2010; Fricke, Chang, and Yang 1994). Normally the future of the family would therefore be safeguarded by sons who married and then themselves had sons to continue the line. Yet, adoption could play an important role if these conditions were not met. For instance, when a couple were not able to have any children, adopting a child could be an important household strategy to ensure family continuity. Adopting a boy could directly provide a male heir, or alternatively a daughter could bring in a husband with the possibility of new grandsons being born. Many have therefore argued that adoption was in itself an integral part of the East Asian demographic system in the past (Feng and Lee 1998; Kim and Park 2010; Kurosu 2010; Kurosu and Ochiai 1995; Wolf and Huang 1980). Although most of the work focusing on adoption has studied the receiving end - households adopting children into the family - it is clear that having too many children in a household also causes problems. Besides infanticide (King 2014; Mungello 2008), adopting children out of the household can therefore also be seen as a strategy for dealing with excess children among the households whose successorship is already assured (Hanley 1985).

The focus of this article is on who was adopted out of the household. We also address the question of why children were adopted out, as this may reveal how gender, household composition, and historical context determined life courses. In order to do so, this study investigates child adoption in Taiwan during the period 1906-1940. On the one hand, the Taiwanese case is interesting because there are large regional differences in adoption rates and both boys and girls were adopted. Whereas in northern Taiwan almost half of the total number of daughters were adopted out of the household, in southern Taiwan it was around one in five. An exception is the case of urban areas in northern Taiwan, where fewer children were adopted out of the household compared to the surrounding rural areas. Still, similar social preferences and cultural norms, originating from Confucian culture and a strong patriarchal family system, played an important role in all regions, although economic conditions differed. On the other hand, reliable longitudinal datasets for ten localities, which are available from the Taiwan Historical Household Register Database (THHRD), make it possible to not only study basic descriptive statistics about who is adopted out at what age, but also to take changing household composition over time into account for the early life courses of 55,145 children. In other words, this large and representative sample makes it possible to examine in what ways non-adopted and adopted brothers and sisters increased the risk of being adopted out of the household and in what way this differed across contexts. Lastly, this study also uses advanced multivariate analyses and time-varying variables to offer a new and more complex view on what factors influenced household decision making regarding giving away children for adoption in early twentieth-century Taiwan. 


\section{Background: Adoption Practices in East Asia}

Adoption plays an important part in many societies across time and space for several reasons. First and foremost, it is a way for childless couples or individuals to receive a descendant and/or an heir to their property (Fauve-Chamoux 1998). In addition, by adopting a child, a home can provide for orphans, bastards, foundlings, children of impaired families, or otherwise unwanted children (Walker 2006). While these functions often overlap, the first centres on the adopter, and the second on the adopted (Goody 1969). Moreover, the latter is also a more modern idea, originating in the late nineteenth century when emphasis was given - mainly in Western societies - to the best interests of the child (Swain 2018). Nevertheless, the function of adoption shows that child survival and family continuity were viewed as essential in historical societies in particular, as by many people no future could be imagined without biological or adopted children. This was especially true for Asia where on the one hand individuals and households tried to ensure family continuity through adoption, affiliation or family composition by any means possible if biological children were not available because of conflicts, poverty, infertility or death (Fauve-Chamoux 1998). ${ }^{1}$ On the other hand, it also provided a possibility for the household to dispose of unwanted and/or surplus children in another way besides committing infanticide. The result was that many people experienced - often at an early age - geographical, social and family mobility because adoption was seen as instrumental to solve many family crises for both the households who gave away children for adoption and the ones who adopted them.

For Asia - the geographical area on which this study focuses - the limited number of historical studies that have been done focus mostly on East Asia, study specific villages and only use basic statistical methods. ${ }^{2}$ In general, adoption practices in mainland China are discussed as a legal institution and a customary arrangement which created tensions regarding the ordering of society and the natural world because filial piety, ritual obligations to ancestors and continuation of the family line through sons were changed and thus were subject to human manipulation. Therefore, adoptions were legally and ritually restricted to persons of the same kin group or the same surname, as sons would contribute to part of the same lineage. Yet, reality was often different, as adoptions often occurred outside these groups due to families' belief that a greater distance between the adopted son and his natal family ensured more loyalty and diminished the chance of rivalry within the lineage (Waltner 1990; Watson 1975). Moreover, in some cases adoption could be used as a way to form family alliances.

\footnotetext{
${ }^{1}$ It should be noted that in Europe too, often in association with the Roman conception of property, adoption plays an important role to perpetuate assets and power in the family network (Hekster 2014; Lindsay 2009).

${ }^{2}$ This section of the literature review does not covers research studying Taiwan. However, it should be noted that the first study to really address adoption as a central part of the Chinese family and marriage practices looked at the Hai-shan region of northern Taiwan during the late nineteenth and early twentieth century (Wolf 1968; Wolf and Huang 1980). These and other findings are addressed in section 3.2 to avoid excessive repetition.
} 
A key study looking at the frequency and implications of adoption for Chinese demographic behaviour focuses on son adoption by examining the complete and accurate Qing imperial lineage during the period 1644-1911 (Feng and Lee 1998). It finds that between six and twelve percent of the sons were adopted, and the average age of adoption was around five years. Demographic considerations were key in determining who was adopting and who was giving away sons for adoption: families who adopted out generally had more than one son, while families adopting a son generally had none. About threequarters of the latter group also had no daughters. Interestingly, when over time demographic demands and adoption rates increased, this caused adoption ages to decline and generational distance between the adopter and adopted to increase. In addition, fathers from the low nobility were more likely to supply sons to distant kin. The study also points out a special situation of male adoption in the Qing imperial lineage when widows adopted sons. This can be seen as a strategy to, on the one hand, continue the family line, and on the other hand to secure allowances from the imperial government, as only male members were given access to these allowances. Widows from the lower classes in particular used these strategies. Furthermore, a reason for giving children away for adoption was social and economic mobility. Although most high-nobility families gave away their sons to low-nobility families, these adopted sons became central figures in their new families. In sum, adoption enabled families to find an heir, to obtain financial aid from the government, and to facilitate social and economic mobility. Moreover, this demonstrates that adoption functioned as a safety valve and was in that way an integral part of the Chinese demographic system in the past, which varied according to the levels of mortality and fertility (Lee and Feng 1999). In a recent study on Korea, similar conclusions were drawn (Kim and Park 2010).

In Japan, adoption practices were also used to ensure heirship, and being an adopted son was not an uncommon experience in nineteenth-century Japan. A difference with China and Korea was that the age of adoption was much higher and the vast majority of adoptions were actually of adult males. Similar to China was the fact that adopted sons were not the oldest male in their own household in most cases (Moore 1970; Kurosu and Ochiai 1995). However, a differentiation can be made between two different forms of marriage - when a daughter was present in the household, and when no daughter was present - but the goal of these practices of adoption was the same, namely, to assure a couple that could have children to continue the family line. There was, however, a difference when families turned to adoption as a solution. Adopted sons were required when demographic constraints caused families not to have any sons, when sons were not at an appropriate age, or when sons were considered incompetent as heirs. Still, the emphasis on the need to continue the family line caused the process of adoption to be quite dynamic, as adopted sons were often on probation for the first few years. This resulted in the situation that adoption was not necessarily a life-long commitment, since it was cancelled when families thought the adopted son was inappropriate for the family (Kurosu 1998). When a daughter was present the adopted son could marry her, or when no daughter was present a wife for the adopted son would also 
be sought. The role of adoption was especially important in families with a low number of sons or no surviving sons, which meant that, in particular, lower social status families - which had lower fertility - would have become extinct if adoption were not possible (Kurosu and Ochiai 1995). As a result, adoption can also be seen as a crucial element of the Japanese stem family system, since demographic constraints led families to have no male heir (Fauve-Chamoux 2005; Kurosu 1998).

Studies examining adoption since the 1950s mainly demonstrate the continuity of these kinds of patterns in East Asia. Their focus is, however, more on the reasons for female adoption, because of the attention paid to the increase in domestic adoptions from 1979 onwards in connection to the one child policy, son preference and the phenomenon of 'missing girls' in China (Greenhalgh and Li 1995; Johansson and Nygren 1991; Johnson, Huang, and Wang 1998). In addition, more research has an eye for the individual experiences of mothers who had to give away their children because of the one-child policy, poverty, and disability (Chen 2016; Xue 2011). ${ }^{3}$ In most cases, adoption took place when couples were childless or when they only had sons and families were increasingly willing to adopt girls despite existing son preferences. What is new is therefore that adoption is used as a means for couples who already have children to reach their ideal family size and gender composition of one son and one daughter (Zhang 2006a, 2006b, 2008). In addition, it was also a strategy to circumvent the one-child policy (Liu, Larsen, and Wyshak 2004). More recently Chen et al. (2015) argue that these findings are consistent with the Chinese tradition of little daughter-in-law adoption and son preference because girls were mainly adopted by families with sons, but they were less likely to attend school. This effect was stronger especially when sons were present. Furthermore, historical regional differences are still visible because the provinces in which the little daughter-in-law tradition was particularly common have the largest increase in adoption rates as a way to deal with childlessness or achieve a gender balance between the number of sons and daughters. Adoption has therefore become a solution for a greater number of crises in Chinese families in particular regions: it is not only a way to continue the lineage, but also a way to ensure support for the elderly and for other economic and cultural considerations. From this perspective it also makes sense that whereas in the past childless couples favoured the adoption of a boy, nowadays sons and daughters are to some extent interchangeable. ${ }^{4}$

This study incorporates the findings of these previous studies regarding the occurrence and motivation of adoption. Previous studies have made clear that adoption was an important strategy for family succession and economic considerations, and while adopted sons were preferred, adopted

\footnotetext{
${ }^{3}$ It is important to note that the practice of adopting a future daughter-in-law was outlawed by the 1950s Marriage Act (Zhang 2001).

${ }^{4}$ Some studies even argue that girls were preferred over boys because their social value was higher. They were considered more trustworthy, more reliable, and better able to take care of parents in their old age. Also emotionally they are considered to be closer to their parents (Zhang 2006b). This is also confirmed by Shi (2017) who demonstrates that in rural China more young couples are also willingly having a single daughter. According to her this changes the conventional way we understand the universal preference for sons in China.
} 
daughters could also play an important role in achieving these goals. The perspective of this study, however, differs as it focuses not on why families adopt children into their household, but on why families give away children for adoption out of their household. Almost none of the discussed historical studies pay attention to this difference, and when they do, the focus is on the receiving end that uses adoption to bring children into the household or on social mobility. Furthermore, this study uses much more advanced statistical analyses than previous historical studies. It may therefore offer a different perspective on the nature of adoption and how it fits within historical Chinese family life and the East Asian demographic system. The next section will position research on the family and adoption practices in Taiwan within the international literature and formulate some hypotheses about possible determinants.

\section{Historical Context: Family, Adoption and Variation across time and place in Taiwan}

\subsection{The Taiwanese Family}

The explicit unit of organisation for all society in Taiwan was the family, which is a group of kin who shared property, generally lived under the same roof and shared a cooking stove (M. Wolf 1968). It can be considered the basic unit of consumption and production. The ideal was based on forming an extended family in which adult brothers not only lived together, but also pooled resources, offered mutual support and had an equal inheritance (Thornton and Lin 1994). These households were, however, highly stratified according to the dominant patriarchal hierarchy, implying clear roles based on gender and generation within the family (Santos and Harrell 2017). In all families the final authority ideally resided with the oldest male, which resulted from the fact that males were the only ones who could continue the genealogy and whose membership of the family and lineage extended throughout all stages of the life course. In other words, descent and the lineage were central to the definition of the family in the sense that the duty of a son towards his father not only extended past death itself by means of ancestor worship, but also included having sons himself to continue the lineage (Chu and $\mathrm{Yu}$ 2010). Together with the importance of filial piety backed up by the state, this caused strong parental power that resulted in senior generations taking precedence over junior ones, and men having priority over women. Moreover, the least privileged can even be further differentiated according to whether particular kin were present (Wolf 2005). This is important to take into account when looking further at who is adopted out of the family, as this household hierarchy may also determine who is more likely to be given away for adoption.

While parental power mainly meant male power in patriarchal societies, this did not mean that women had no power within the household (Kok 2010). When looking at the family from a female perspective, one can distinguish a woman's 'uterine' family: the group that centres around her mother and her mother's children, and, after she herself marries, around herself and her children. This uterine family was therefore the group which was created for the needs of a woman and only existed to the 
extent that she had the ability to keep it together. As a result, the uterine family has no clear ideology, no formal structure and no public existence, but one can argue that it is no less real because it is built on the loyalties of its members (Wolf 1972). In many cases, for example, a woman's son could also be her spokesmen and defend her interests. ${ }^{5}$ In addition, since women carried out many of their activities outside the house, they came into contact with other women and formed a community that had some power because honour and appearances, in the sense of 'having face', were very important for a family. It was also more easily lost than restored. In many ways, therefore, including this female perspective demonstrates that women in rural Taiwan did not only live their lives in the houses of their husband's family, although this differed from individual to individual because certain techniques and skills were required to wield this power in household decision-making.

Marriage was the foundation on which the family line could be continued and therefore parents, as with all major events in historical Chinese families, took the initiative and arranged marriages for their children with great care (Wolf 1972; Wolf and Huang 1980). This is important to note, as the preference and interests of an individual may be completely different and even opposite to that of the household and vice versa. Marriage was not on based on love, but can be seen more like a kind of business deal in which most of the time a bride and a groom only saw each other for the first time briefly before the wedding, or on the wedding day itself (Engelen and Hsieh 2007). The importance of marriage for family continuity and the extent to which parental power influenced life courses meant that marriage - and as a result the Chinese family - could vary a lot. Most marriages in Taiwan can be classified as belonging to one of three types: major, minor and uxorilocal (Wolf and Huang 1980). Marriages performed in the major fashion were probably most common in Chinese societies as this was the 'proper' way to marry. Another type of marriage was the minor form. In a minor marriage, a sim-pua, or little daughter-in-law, would be adopted into the family at a very young age to be a future bride to a son of the couple adopting her. The main difference between a major and minor marriage was therefore the timing and the ceremonial complexity of the marriage, which also resulted in lower costs. The third and final form found was uxorilocal marriage. While in most cases the daughter left her family to join her husband's family, in this form of marriage the husband married into the bride's family (Wolf 1972, 1995; Wolf and Huang 1980).

The result of parental authority being absolute during a person's life was that families manipulated their composition to solve immediate problems and to achieve long-term goals regarding

\footnotetext{
${ }^{5}$ It is important to make an observation about the status and role of women within the family after they married. As already mentioned, there was a strong emphasis on producing descendants, couples generally married at a young age, and all women married in the end. A woman's position was, however, only strengthened when she bore her first child. If the first-born child was a girl, the wife established her position as part of the family of her husband because it was clear that she was able to conceive. When a son was born, however, this ensured that her influence in the would only grow, as she had direct influence on the son, who could speak on her behalf (Wolf 1972).
} 
the continuation of the family line (Wolf and Huang 1980). This meant that there could be much variation and flexibility in the intensity of lineage and family organisation in Taiwan with regard to how marriage and adoption were used, as it would simply be adapted to the circumstances. Despite the fact that family members have common objectives as well as conflicting ones, it is, however, clear that the senior generations of both genders maintained son preference. While sons were more valuable than daughters for men because sons were needed to continue their lineage, for women the same was true because the power of women resulted from their influence on their sons. Moreover, for the creation of a harmonious uterine family, daughters could be better exchanged for little daughters-in-law since a woman could raise her daughter-in-law according to her wishes and a potential rival for her son's attention was neutralised at the same time. In short, giving away sons for adoption can be seen as an extreme measure, while giving away girls can be seen as beneficial for the future of the household from a parental perspective.

\subsection{Male and Female Adoption}

The general international literature already demonstrates that adoption is a central part of the Chinese family and marriage practices. Yet, what has not previously been discussed is the research looking specifically at adoption practices in Taiwan because they differ to some extent, mainly through the inclusion of female adoption practices (Wolf 1968; Wolf and Huang 1980). This difference is important, as the literature on early-twentieth century northern Taiwan demonstrates that more than half of the girls were adopted out of the household as 'little daughters-in-law' and about fifteen percent of the boys were adopted out as sons or sons-in-law. The practice of adopting many little girls as future wives for the sons of their in-laws caused adoption to occur at a very early age and meant that marriage would be inexpensive when they married each other in their teenage years. Moreover, while these studies cover only a relatively small region of Hai-shan during the period 1850-1940, they provides much qualitative evidence from China that suggests that the people in Hai-shan were not exceptional in their marriage practices. Yet, the custom was little talked about or was even criticised by the Chinese themselves, which could, according to Wolf (1968), be the reason why many studies do not discuss these kinds of adoption practices. Still, the evidence of regions outside of Taiwan remains very anecdotal, meaning that most research is only possible for Taiwan as it is the only place where large-scale quantitative research is possible when investigating male and female adoption at an early age. ${ }^{6}$

In general, male adoption is less complex compared to female adoption because it is more straightforward regarding people's goals and decision-making processes. In most cases, a boy was adopted into a family as an heir to continue the family line, all natal kinship ties were broken, and a large sum of money had to be paid to the boy's natural parents. The adopted son thus became the

\footnotetext{
${ }^{6}$ Moreover, other studies also investigate what kind of effect adoption had on the mortality and fertility of adopted girls (Mattison et al. 2015, 2018; Riswick 2013; Wolf 1995).
} 
exclusive property of the adopting family. A difference, however, was made in the case when no compensation was asked and a child was taken from a recognised agnate, which meant he had property rights in his adopting family, but retained strong ties with his natal family (Saso 1999; Wolf and Huang 1980). Next to ensuring the family line, boys were sometimes adopted by widows soon after the husband died, for economic reasons as well as family continuity. This can be seen as a kind of posthumous adoption in which the adopted boy would become entitled to inherit the estate, thereby giving the widow access to it (Pasternak 1983). However, in order to understand why families would give up sons for adoption, and thereby remove them from their own households, one must take also take son preference and the patriarchal system into account. Because sons were key in continuing the family line, only households who had many sons would give some of them away for adoption. In addition, households with lower socio-economic status would be more susceptible to giving out sons for adoption as this would provide needed extra income. This may be especially true for sons born in illegitimacy, as this is often an indicator of lower socio-economic status.

The motivation behind adopting girls is more complex, as there are many different types of adoptions and consequently the reasons for adoption are also more diverse (Wolf and Huang 1980). Due to this widespread practice of adopting a young girl to be the future bride for the son of the family, the Japanese even found it problematic to identify a single source for the practice (Saso 1999). Furthermore, the high numbers of little daughter-in-law adoptions can be attributed in particular to the negative attitude of the Japanese towards the adoption of female servant-slaves, which was even forbidden after 1916, and the higher esteem and social status attached to the little daughter-in-law form of adoption. This means that in the available sources it is difficult to make a clear distinction between the different types of adoption. Despite this disadvantage, many scholars have argued that most female adoptions were probably defined as little daughters-in-law by the Taiwanese themselves as well. This caused them to have certain privileges associated with having entered the family through marriage. Moreover, the type of adoption would be irrelevant, since it did not mean that a little daughter-in-law had a particular role within the household and in turn the type or reason for adopting a girl did not matter much for how her life would play out, as this would be determined by the particular situation of a household. Normally this meant that any adopted daughter would be treated as a kind of servant, which is also illustrated by how interviewed women note that an adopted daughter was more useful because she could be pushed more to work harder than their own daughter (Wolf 1972).

The first and foremost reason why people adopted girls was so they could function as futurewives for their sons. Economically this minor marriage was a much less expensive form of marriage. Culturally, especially from the viewpoint of the uterine family, a stranger would not enter the household as an adult, but as a child, meaning that the mother-in-law could bring up and shape the behaviour of her future daughter-in-law, causing their relationship to be much smoother and more harmonious than 
it otherwise would be (Saso 1999; Wolf 1972). ${ }^{7}$ A second reason is that adoption may work therapeutically. Newlyweds, or couples who took longer than expected to conceive, adopted a little daughter-in-law because they believed it would stimulate the conception of a son. In other words, having the future wife already there, the husband would soon follow. Similarly, a daughter could be adopted into the family to replace a child who died. A third reason to adopt a girl was to have a kind of servant who could help with the household chores, take care of ill or elderly childless couples or individuals, or fulfil ancestor obligations. Lastly, people may also have adopted girls because they simply wanted to have daughters. In contrast to the often asserted uselessness of daughters in Chinese families, in many regions they actually carried out domestic tasks of considerable value. In addition, when women's mobility was not limited by the practice of foot binding, they were also capable of undertaking agricultural tasks, which meant they contributed directly to the available household resources (Pasternak 1983). In short, all these reasons suggest that, when women were needed for specific socio-economic reasons, or to fulfil obligations owed to ancestors, there was a disincentive to adopt them out of the household.

The little that is known about the motivation of people giving female children away for adoption suggests that same-sex sibling position greatly affected who was adopted out of the household, in the sense that only children were seldom given out in adoption. For boys this meant that if they were adopted out, it would be the responsibility of another male to continue the family line. This is, however, also true for girls, as daughters were not simply given away because they were female. They only became surplus when there was another way to secure the future of the family line, such as when a brother or older sister was present. Some descriptive results for specific regions underscore this reasoning by demonstrating that adoption risks are higher for later-born children (Pasternak 1983; Saso 1999; Wolf and Huang 1980). Next to having enough children to ensure family continuation, having too many, especially when families were too poor to support their children, could also be a reason for adopting out children. The question about how many, and which, children are needed in the household differs according to the economic circumstances of a household, especially when resources are scarce. Because it was possible to give away unwanted children for adoption, many have argued that this caused infanticide to be uncommon in Taiwan (Saso 1999), but the same mechanism may still be at work to determine who is given away for adoption.

\footnotetext{
${ }^{7}$ Wolf (1972:176) describes this very well: "The sim-pua form of marriage is not a custom that is likely to be revived, but it is one of the more interesting strategies human beings have devised to ensure the continuation of their families. If (as many anthropologists and some Taiwanese farmers say) a strong bond between husband and wife is a major threat to the patrilineal system, the sim-pua marriage was surely an excellent safeguard (...) It gave a woman maximum control over the members of her uterine family. By substituting a daughter for a daughter-inlaw, she exchanged an enemy for an ally and removed the major threat to her exclusive ties with her son. The great popularity of the sim-pua form of marriage may have had more than a little to do with the fact that women arranged marriages. It is ironic that they both gained the most and suffered the most."
} 
An example of household decision making with regard to who is needed in the household and who is not is the case of a daughter who is given away when a little daughter-in-law was adopted into the household as described earlier. In practice, there are many instances in which a daughter is given away soon after a little daughter-in-law is adopted into the household. In a way, this can be seen as a strategy in which a useless daughter is - although not literally - exchanged for a useful little daughterin-law, as resources are only invested in permanent family members (Wolf and Huang 1980). Another specific situation in which poverty may have played a role was when children were born in illegitimacy. These children have higher mortality risks because of social norms stigmatising illegitimate births and because mothers often lived in unfavourable economic conditions (Barrett 1980; Gates, Kok, and Wang 2006; Lin 2013). In other words, to have a sexual relationship with someone without marrying him can be seen as a desperate measure, but it can also be considered necessary for a woman of a poor family struggling to make ends meet, as non-marital relationships provided an important alternative source of support and even a means of building a family. Yet, in the Penghu Islands, illegitimate girls were not subjected to the risks of adoption in greater proportions than legitimate girls. Illegitimate boys, however, were given out in adoption more frequently than legitimate boys (Yu, Huang, and Chuu 2011). Lastly, superstitious belief, such as being born on an unlucky day or other omens, could lead to a child's being adopted out of the household too, which can be attributed to cultural norms (Okoda 1949).

Despite these reasons given in the literature, it should be noted that an important factor is missing: the people involved in the decision-making process. Women themselves often had no choice in the decision-making process when children were adopted out of the household, since all arrangements were made by the mother-in-law. Especially when mothers-in-law were in their prime and mothers were still young, the latter had little say in the fate of their children (Wolf and Huang 1980). Moreover, these decisions were most often based on who else was available in the household to take care of people, and on the persons who had to be taken care of. First of all, the presence of grandparents can be seen as key, not only because this older generation in most cases determined who was adopted out of the household, but also because they could offer support and devote time and attention to their grandchildren (Diamond 1969; Sear and Mace 2008). The gender, age and number of siblings might be important in this regard too, as these not only determined whether family continuity could be secured, but also to what extent siblings competed over tangible and intangible resources or were actually able to offer support in the sense of generating enough resources that giving away children for adoption was not an inevitability (Riswick and Hsieh, forthcoming). Lastly, the marriage type of the parents may also be an indicator of certain norms in a household, regarding to what extent minor or uxorilocal marriages were seen as acceptable alternatives to a major marriage. This may be especially important as marriage types greatly influenced later life transitions and individual demographic outcomes (Wolf 1995). 


\subsection{Differences in marriage and adoption between regions and over time}

In northern Taiwan, marriage did not follow the major marriage pattern found in most Chinese areas. The patterns that were found can best be characterised as ones in which minor marriages tended to replace major marriages as the preferred form of marriage. This meant that between 30 and 50 percent of all marriages involved the adoption of young girls as a way to secure a future minor marriage. In central and southern Taiwan, marriage was a radically different institution from that in northern Taiwan: between 65 and 95 percent of the marriages were major marriages. The difference in the frequency of minor marriages is even sharper, as the highest level that can be found in a village is only 15 percent. The frequency of uxorilocal marriages is on average almost the same in the south and the north, around 12 percent. Yet, the distribution of this type of marriage was highly irregular, which may indicate that it was a local rather than a regional phenomenon (Chuang and Wolf 1995; Li et al. 2019; Lin, Yang, and Chuang 2014; Wolf and Huang 1980). These differences in marriage patterns also affected the chance of being given away for adoption before age fifteen for girls especially: for northern Taiwan the average ranged from 45 to 66 percent, while in southern Taiwan it ranged from 12 to 17 percent.

The most common explanation for the observed regional difference in the frequency of the types of marriage and adoption rates between northern and southern Taiwan is the difference in marriage markets. ${ }^{8}$ The very high frequency of minor marriages in northern Taiwan was a direct result of an unbalanced sex ratio and an affluent economy. In short, because of the successful development of the tea trade, many unskilled and skilled labourers were attracted to the cities. This large number of mostly unmarried men caused a demand for unmarried women that could not be satisfied by the locally available supply. As a result, women living in the villages and towns in the periphery were pulled out to the city which in turn drove down age at marriage to the point that many people were forced to adopt a girl at a very early age with the objective of providing a future wife for their son. In the north, people were therefore never forced to raise a daughter because they could easily find people who were looking for a little daughter-in-law (Chuang and Wolf 1995). Even more, families may even have been forced to marry their sons in the major fashion because there were not enough girls given away for adoption. In contrast, in southern Taiwan it was not the norm to adopt girls as future wives because economic conditions were different (Cohen 1976; Wolf and Huang 1980). In sum, a shortage of women and a surplus of wealth generated a marriage market hot enough to raise the frequency of minor marriages in the north, while in the south this did not occur (Chuang and Wolf 1995).

\footnotetext{
${ }^{8}$ Scholars have also pointed at the different migration histories of the two regions which could have influenced different cultural norms. While the south was colonised by farmers recruited by the Dutch and the soldiers of various armies of the Cheng regime in the $17^{\text {th }}$ and $18^{\text {th }}$ century - mostly unmarried men who must have married with the locals from the Plains Aborigine tribes - the north became occupied at the end of the $19^{\text {th }}$ century by a flood of land-hungry farmers who brought their families and wives with them. This could have caused a rejection of the minor form of marriage in the south where the mixed marriage created a more egalitarian atmosphere (Chuang and Wolf 1995).
} 
Besides regional variation, earlier studies also observe variation over time in adoption practices, especially in those which are connected to minor marriages. In the 1920s and 1930s, the frequency of minor marriages declined abruptly, which cannot be explained by a dwindling supply of little daughtersin-law or an end to the practice of parents raising wives for their sons, as the decline in adoption rates accompanied it. It is therefore argued that this change came not from the senior generations, but from the junior ones who resisted the idea of marrying someone with whom they were raised from childhood onwards. This aversion caused by intimate childhood was, however, not specific to the period in which adoption rates declined, but also persisted before this period. ${ }^{9}$ The difference during the 1920s and 1930 can therefore be found in socio-economic changes: young people had the opportunity to learn new skills by moving from agriculture to occupations that offered an alternative way of making an independent living. These changes caused the young to revolt in the sense that children would have the possibility of leaving the household because of their aversion to marrying their adopted sister. Although few actually left the household, it meant that parents would be more willing to listen to their children's wishes regarding who not to marry (Wolf and Huang 1980). Next to these changes, which mainly affected little daughter-in-law adoption, child mortality also declined while fertility stayed at the same level, causing fewer children to die (Barclay 1954; Liu 2004). In turn, the demand for adopted children as a solution to not having an heir, or for therapeutic reasons, was much lower, which may also have resulted in fewer children being given away for adoption in the period after 1925 .

\subsection{Hypotheses}

We have extensively discussed the literature on adoption practices in East Asia in general, and family characteristics and reasons for adopting and giving away children for adoption in Taiwan more specifically. First of all, previous literature has already argued that there are important differences in gender and birth position among siblings of the same sex for the chances of being given away for adoption. Girls were given away for adoption more often than boys, but for sons and daughters separately being later-born should increase adoption risks. Another mechanism mentioned in previous literature is that parents especially exchanged daughters after adopting a little daughter-in-law who would marry their son in the future. If this practice is widespread, having an adopted girl in the household should increase adoption risks. The same may be true for daughters when an adopted boy is present as the household had already secured a way to continue the family line. For sons, however, we do not expect higher adoption risks when adopted children are present, as in general sons would seldom be seen as surplus in a household. An exception to this rule may be households of a low socio-economic status, as the sale of a son could provide needed extra income. In contrast, we expect farmers to be less likely to give away sons as their labour is needed in the household, which may also result in daughters

\footnotetext{
${ }^{9}$ More information about this can be found in Wolf (1995), who based his work on incest avoidance to a great extent on his field research in Taiwan.
} 
being given away more frequently because of the expenses involved in raising many daughters who only add limited resources to the household and would have to be given away for marriage eventually. Regarding ethnicity, formulating any hypothesis is difficult as it is connected to socio-economic status and the specific regions. Yet, we do expect that Hakka and Hokkien used adoption much more than other ethnicities (Shepherd et al. 2006).

Next to the previous hypotheses, new hypotheses can also be formulated by going beyond the existing literature, but by following the logic of household decision-making in Taiwan. First, grandparents may influence the risks of being given away for adoption because it is easier for them to give away a child than it is for the child's own parents. At the same time, however, when grandparents, especially a grandmother, were available, they would be able to help with taking care of younger children in the household. The same may be true for older siblings, while many young siblings may be a reason for households to give away some children to relieve the childcare burden. Second, illegitimacy is interesting to incorporate as illegitimate children generally were born in poor households, which could motivate mothers to give away their sons for adoption because of the financial compensation they received, while for daughters the opposite may be true as they could be a way to secure care in old age. Third, while parents may want to replace a child who died by adopting another child, the opposite may also be true: parents who lost a child may be less likely to give away their next child for adoption. Lastly, the marriage type often had considerable influence on demographic outcomes (Wolf and Huang 1980), the question is, however, whether it also matters for the risks of adoption. One could, for example, argue that in households where major marriages are the norm, parents will also try to arrange a major marriage for their children. The same may be true for minor marriages and other marriages not conforming to the norm.

The discussed regional variation in adoption rates, especially between northern and southern Taiwan, makes it possible to not only investigate who in general was adopted out of the household and why, but also to study whether the causes for giving away children are different, and if so, whether these differences can be attributed to economic and cultural variations between these areas. In the northern regions where adoption was common we may expect that girls were adopted out of the household whenever possible. In that sense, the fact of being a girl - and so, gender - would be more important than birth order. In addition, because daughters would be exchanged for little daughters-in-law, the entrance of such an adopted daughter into the household should greatly increase the risk of being adopted out. In southern regions where adoption was less common birth order could be more important as it was a more alternative strategy. As a result, it can be hypothesised that only when households had too many daughters would they be adopted out of the household. For boys we do not expect any regional differences. Lastly, we would expect that adoption risks in all regions decrease over time because of economic and demographic developments. 


\section{Data, Measurements, and Methods}

In this research the Taiwan Historical Household Registers Database (THHRD) is used, which is maintained by the Program for Historical Demography (PHD) at Academia Sinica, Taiwan. This database contains the digitised data from the household registers of Taiwan compiled in the Japanese colonial period. Taiwan was ruled by Japan from 1895 to 1945, and in 1905 the Japanese colonial government began to implement a household registration system administered by the police to tightly monitor and control the people in Taiwan. Under this registration system, every person had to register with the police as a member of one household. The personal information required in a household register included name, relation to the household head, significant personal life events and the dates of these events, occupation, class (zucheng族族稱) for Japanese, race (zhongzu種種族) as inherited from one's biological father, whether feet were bound (for females), which immunisations had been received, and whether they were addicted to opium. Household heads had the responsibility of reporting any changes to a local registry office (usually a local police station), and the police would pay regular and irregular home visits to make sure that the information in the registers was accurate. In order to enable people to follow the regulations for reporting adoption correctly, the Japanese government announced in the newspaper when the regulation changed (see Figure 1). These household registers, containing considerable demographic details at an individual level, have mostly been preserved to the present. They offer us the possibility of following individuals on a day-to-day basis, which is key since in a pretransitional society, as high mortality, adoption, marriage, and migration could change household composition considerably. To be able to take this into account is a major strength of the current study.

Figure 1: News article "Reporting population changes", Taiwan Daily News, 14th, October, 1905

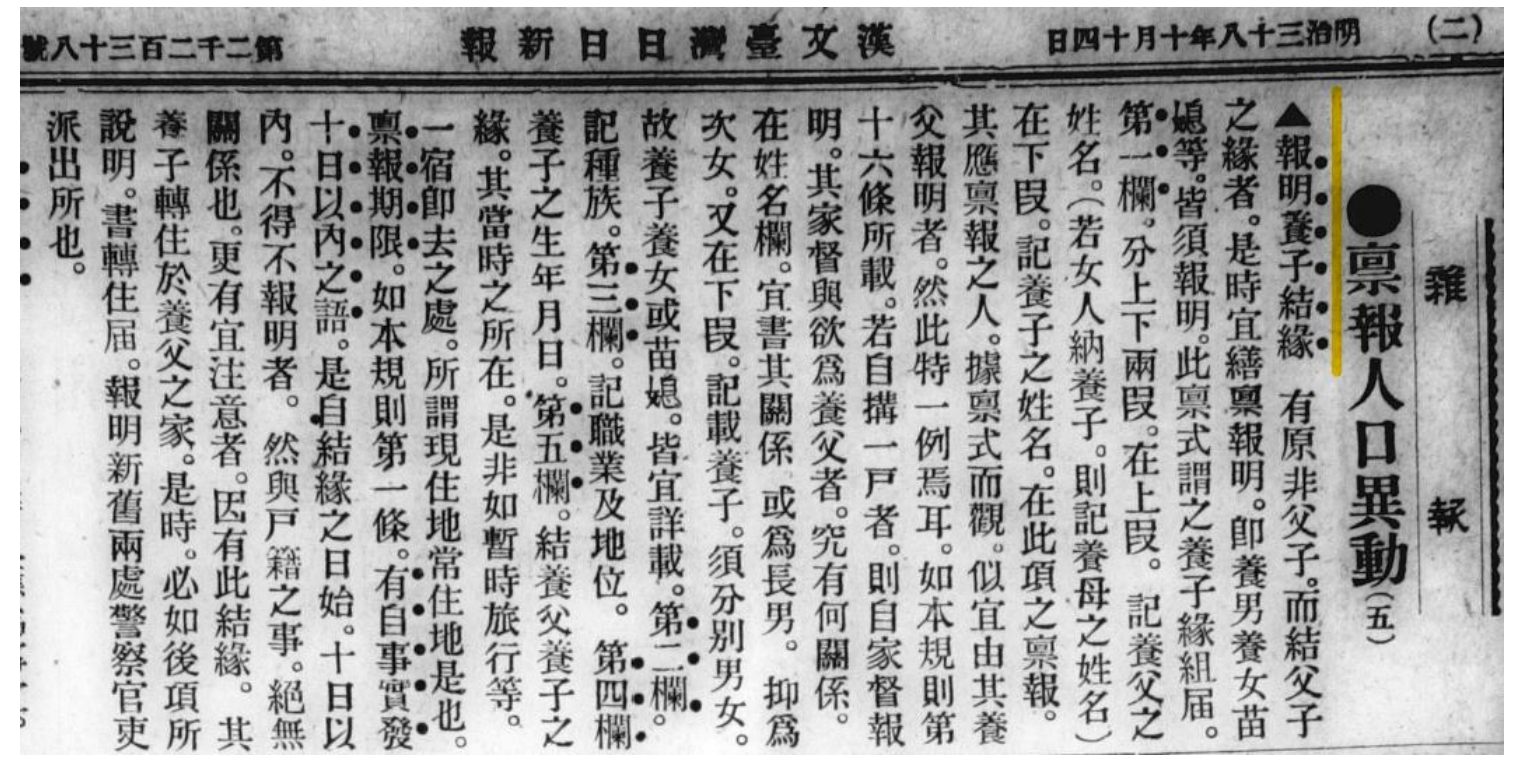

The Program for Historical Demography has collected the historical household registers from 26 study sites and transcribed the registration data of 18 study sites into the THHRD database, which provides a large population sample for historical demographic analysis (see Figure 2). The sample of 
the THHRD for this paper consists of all children who were born between 1906 and 1940 from the research areas of Mengjia and Taodaocheng (1), Zhubei (04), Beipu (05), Emei (06), Guanxi (07), Danei (13), Jibei (14), Donggang (15), and Jiuru (16). It is important to note that all children from each household are selected as research persons, which means that observations are clustered within households. A further selection was made by only including children who can be observed from birth onwards. To analyse all data, methods appropriate for the statistical analysis of quantitative life course data are used. The univariate analysis is carried out by employing Kaplan-Meier curves, while multivariate event history Cox proportional hazard models can analyse adoption risks by taking time and control variables into account (Broström 2012). Observation time begins with the birth of a child and ends when it is adopted out (failure event) before his or her fifth birthday. All remaining children (which are research persons) are censored after their fifth birthday, or earlier when they could no longer be observed. It is important to note that this means that only first adoptions are included in this sample. ${ }^{10}$ The models are clustered by family identity to adjust standard errors, thereby allowing for interfamilial correlation. Cox proportional hazard models are presented in Tables 2 and 3. Probability values of less than 0.05 are assumed to represent statistical significance and diagnostics were run to check whether all assumptions were met.

In Table 2, the main variable of interest is the same-sex birth order, which is defined as the birth position among siblings of the same sex with the same mother. It is important to note that the same-sex birth order is treated as a time-varying covariate. This accommodates the fact that siblings could move in and out of the household while the index child was growing up. Kin that has the most important influence on life course transitions according to the literature - namely the grandparents - are also included as time-varying variables. Next to the time-varying birth order a dichotomous variable is also included to measure whether an adopted sister was present, in order to make it possible to see if this increased adoption chances for girls as the exchange of a daughter for a daughter-in-law would suggest. The same is done for an adopted brother, and both these variables are also time-varying. The occupation of the household head and ethnicity are added to examine how economic conditions and cultural norms affect adoption risks. By including the region and time period it is possible to study differences in time and place in which the research persons lived. Next to these variables, being an illegitimate child and whether a previous sibling died before the age of five may also be important for adoption risks. Lastly, marriage type is also included for the same reasons. In Table 3, same-sex birth order is replaced by a time-varying dichotomous variable which represents the presence of non-adopted and adopted brothers

\footnotetext{
${ }^{10}$ Adoptions could also be cancelled, which in general meant that the child returned to its natal household. Because the goal of this study is not to investigate the dynamics of adoption practices, but only the determinants of giving children away for adoption, only first adoptions out of the household are used. In addition, for our study it does not matter if children that were given away for adoption return, as the focus is on the incentive of what causes households to give children away for adoption.
} 
and sisters in specific age categories. By doing so, the influence of sibship composition can be studied in more detail (see also Riswick and Hsieh, forthcoming).

Figure 2: Map of the research sites of available in the THHRD

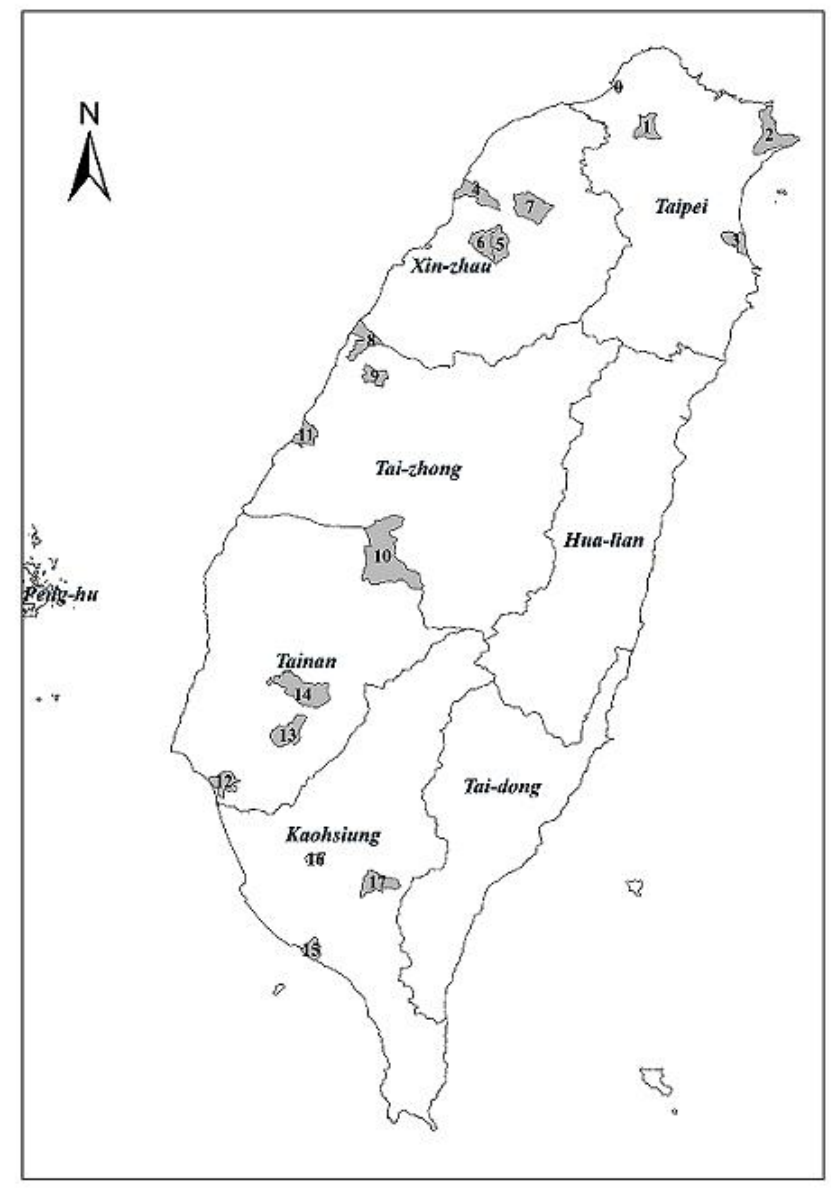

The research sites selected for this study are: Meng-jia \& Tao-dao-cheng (1), Zhubei (04), Beipu (05), Emei (06), Guanxi (07), Danei (13), Jibei (14), Donggang (15), and Jiuru (16). Source: Program for Historical Demography, Research Center for Humanities and Social Sciences, Academia Sinica.

The summary statistics of all variables - measured at the moment when the research persons were born - are presented in Table 1. It demonstrates that the selection includes slightly more boys compared to girls, as may be expected given that more boys are born compared to girls, just as the number of persons for each birth order decreases when birth order increases. Slightly fewer than half of the children had a grandmother and/or a grandfather present in the household. About a quarter of persons have an adopted sister, while only 3 percent have an adopted brother. This already demonstrates the large gender differences in adoption risks. Hakka is the largest ethnic majority and the head of most families was a farmer. Around 7 percent of the persons are born in illegitimacy, and in 13 percent of cases the previous sibling died before the age of five. The research persons are evenly distributed across the time periods, although this is not the case for the regions under study. 
Table 2: Descriptive statistics of research persons at birth in the selected research areas in Taiwan,

1906-1940

\begin{tabular}{|c|c|c|}
\hline \multirow{2}{*}{ Variables } & \multirow[t]{2}{*}{ Number } & \multirow[t]{2}{*}{$\%$} \\
\hline & & \\
\hline Male & 28721 & 52,1 \\
\hline Female & 26424 & 47,9 \\
\hline \multicolumn{3}{|l|}{ Adopted sister } \\
\hline No & 42253 & 76,6 \\
\hline Yes & 12892 & 23,4 \\
\hline \multicolumn{3}{|l|}{ Adopted brother } \\
\hline No & 53659 & 97,3 \\
\hline Yes & 1485 & 2,7 \\
\hline \multicolumn{3}{|l|}{ Grandmother present } \\
\hline No & 29431 & 53,4 \\
\hline Yes & 25714 & 46,6 \\
\hline \multicolumn{3}{|l|}{ Grandfather present } \\
\hline No & 33537 & 60,8 \\
\hline Yes & 21608 & 39,2 \\
\hline \multicolumn{3}{|l|}{ Birth order } \\
\hline 1 & 11736 & 21,3 \\
\hline 2 & 10267 & 18,6 \\
\hline 3 & 8906 & 16,2 \\
\hline 4 & 7309 & 13,3 \\
\hline $5+$ & 16668 & 30,2 \\
\hline Unknown & 259 & 0,5 \\
\hline \multicolumn{3}{|l|}{ Occupation head } \\
\hline Farmers & 34119 & 61,9 \\
\hline Low SES & 9202 & 16,7 \\
\hline High SES & 8301 & 15,1 \\
\hline Unknown & 3523 & 6,4 \\
\hline \multicolumn{3}{|l|}{ Ethnicity } \\
\hline Hokkien & 18673 & 33,9 \\
\hline Hakka & 27175 & 49,3 \\
\hline Other & 9297 & 16,9 \\
\hline \multicolumn{3}{|l|}{ Illegitimate } \\
\hline No & 51543 & 93,5 \\
\hline Yes & 3602 & 6,5 \\
\hline \multicolumn{3}{|l|}{ Previous child died } \\
\hline No & 47923 & 86,9 \\
\hline Yes & 7222 & 13,1 \\
\hline \multicolumn{3}{|l|}{ Period } \\
\hline 1906-1925 & 28943 & 52,5 \\
\hline 1926-1940 & 26202 & 47,5 \\
\hline \multicolumn{3}{|l|}{ Region } \\
\hline Zhubei (north) & 6693 & 12,1 \\
\hline Beipu (north) & 8461 & 15,3 \\
\hline Ermei (north) & 4547 & 8,2 \\
\hline Guanxi (north) & 15090 & 27,4 \\
\hline Danei (south) & 7013 & 12,7 \\
\hline Jibei (south) & 1297 & 2,4 \\
\hline DongGang (south) & 2513 & 4,6 \\
\hline Jiuru (south) & 2213 & 4,0 \\
\hline Mengjia (Taipei) & 3683 & 6,7 \\
\hline Dadaocheng (Taipei) & 3635 & 6,6 \\
\hline
\end{tabular}




\section{Results}

\subsection{Univariate results}

In the areas in our study, out of the 26,424 girls born, 7,016 (27\%) were adopted out of the household before age five, while the number is much lower for boys, where only 1,030 boys (4\%) of the 28,721 boys born were adopted out of the household before age five. Figure 3 shows a Kaplan-Meier curve for the adoption risk in days from birth until age five for boys and girls separately. It demonstrates not only the large gender difference, but also that most adoptions took place between the first two years of life. For example, of the girls who would be adopted out of the household, almost half of them were already adopted out before their first birthday. When looking at the children who are adopted out before age five, the mean age of adoption is 450 days for girls and 426 days for boys, while the median is 311 days for girls and 265 days for boys. It therefore seems that although girls do indeed have much higher adoption risks, boys are adopted earlier out of the household. This difference can be explained by the greater demand for boys. Lastly, since these first results demonstrate that adoption risks differ significantly between boys and girls, it is important to examine relevant factors separately for each gender.

Figure 3: Kaplan-Meier curve for boys and girls in Taiwan, 1906-1940

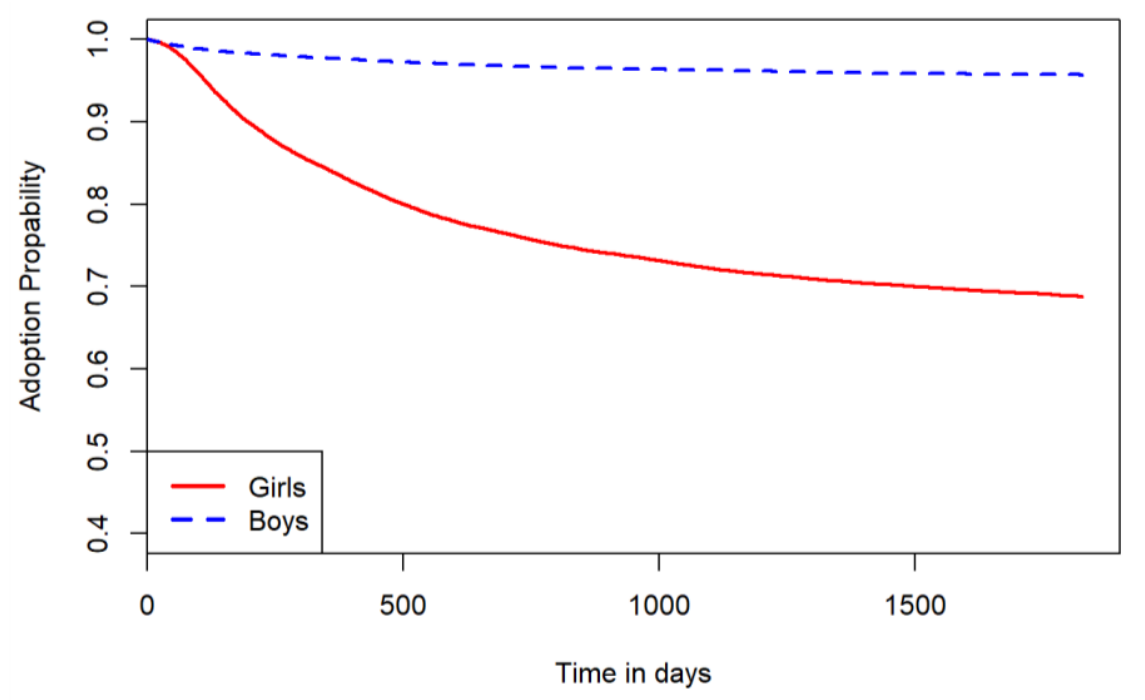

From the literature we would expect that the same-sex birth order would also matter a great deal for adoption risks as parents would be hesitant to adopt out their only son or daughter. In Figure 4, therefore, the Kaplan-Meier curves for adoption risks of same-sex birth order of boys and girls are shown. It demonstrates that for both boys and girls being a later-born child causes adoption risks to be much higher. Although for boys the adoption risk is low compared to girls, for first-born sons the adoption risk until age five is below 1 percent, while for third- or later-born sons the adoption risk until age five is around 8 percent. For boys any additional brother gradually increases the risks of adoption. 
For girls a similar pattern can be observed, but in particular the differences between being the first daughter and being a later-born daughter are striking. For being the first-born daughter the adoption risk until age five is around 21 percent, but this is much lower compared to being second-born (37 percent), and third- or higher-born (39 percent). In addition, girls who are not the first-born daughter in a household in particular are given away for adoption much more quickly, and at a much earlier age. It confirms the idea that children would only be adopted out when there was a way to secure the family line, which mainly meant that an older sibling, mostly a brother, was already present.

Figure 4: Kaplan-Meier curve for same-sex birth order for boys and girls in Taiwan, 1906-1940

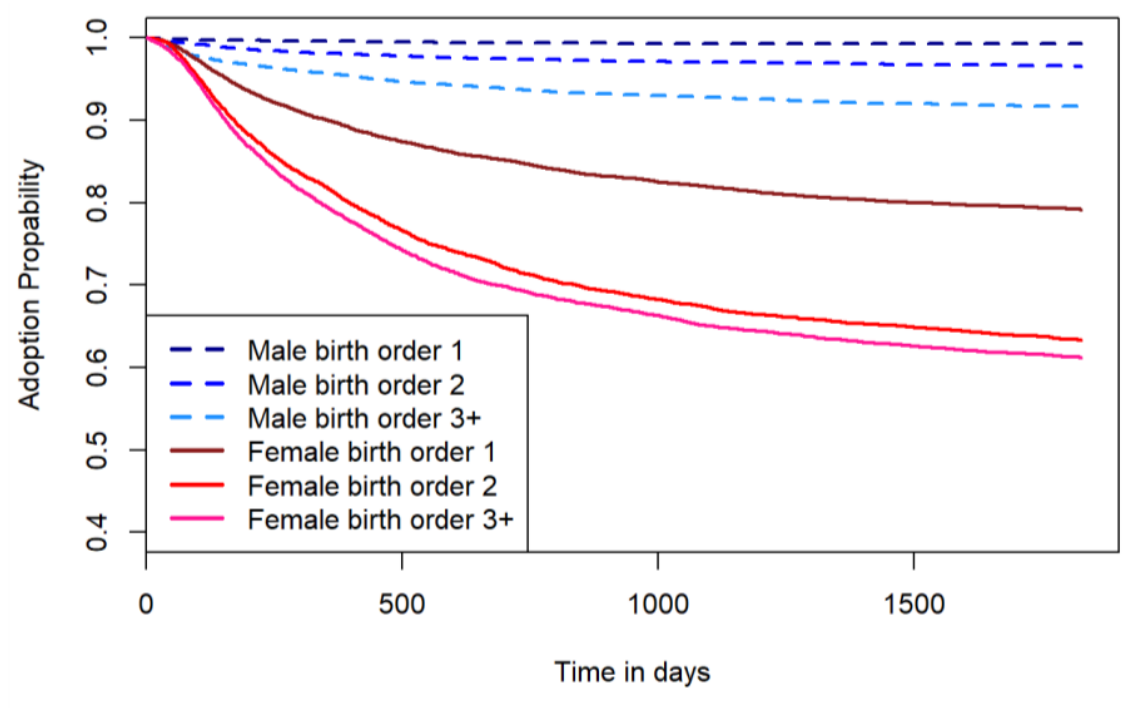

Despite the clear differences in gender and same-sex birth order, it is also important to take regional variation into account, as many studies have shown that in northern Taiwan adoption was much more common compared to southern Taiwan. In Figures 5 and 6, therefore, the Kaplan-Meier curves for adoption risks by gender are shown for each of the regions separately. For the adopted boys it is difficult to see clear differences, but the rural northern regions (Zhubei, Beipu, Emei and Guanxi) have the highest adoption risks for boys, between 4 and 6 percent until age five. For the southern rural regions (Danei, Jibei, DongGang and Jiuru) this is between 2 and 3 percent. The regions representing urban northern Taiwan (Mengjia and Dadaochen) are in between, with male adoption risks around 4 percent until age five. For girls, the same regional variation in differences in adoption risks are observed: adoption risks of girls are much higher in rural northern Taiwan compared to rural southern Taiwan. For northern Taiwan, between 38 percent and 43 percent of the girls are given away for adoption, while for southern Taiwan only between 3 and 8 percent of the girls are adopted out of the household before age five. The adoption risks of girls in urban northern Taiwan are again in between northern and southern rural Taiwan with around 25 percent of girls being adopted out of the household. It is striking, however, how in the first year of life adoption risks are the same compared to rural northern Taiwan, but thereafter the adoption risks only increase in the rural areas. This suggests that apparently parents would already 
decide in the first year whether a daughter would be given away for adoption, or whether they would raise her themselves.

Figure 5: Kaplan-Meier curve for each region for boys in Taiwan, 1906-1940

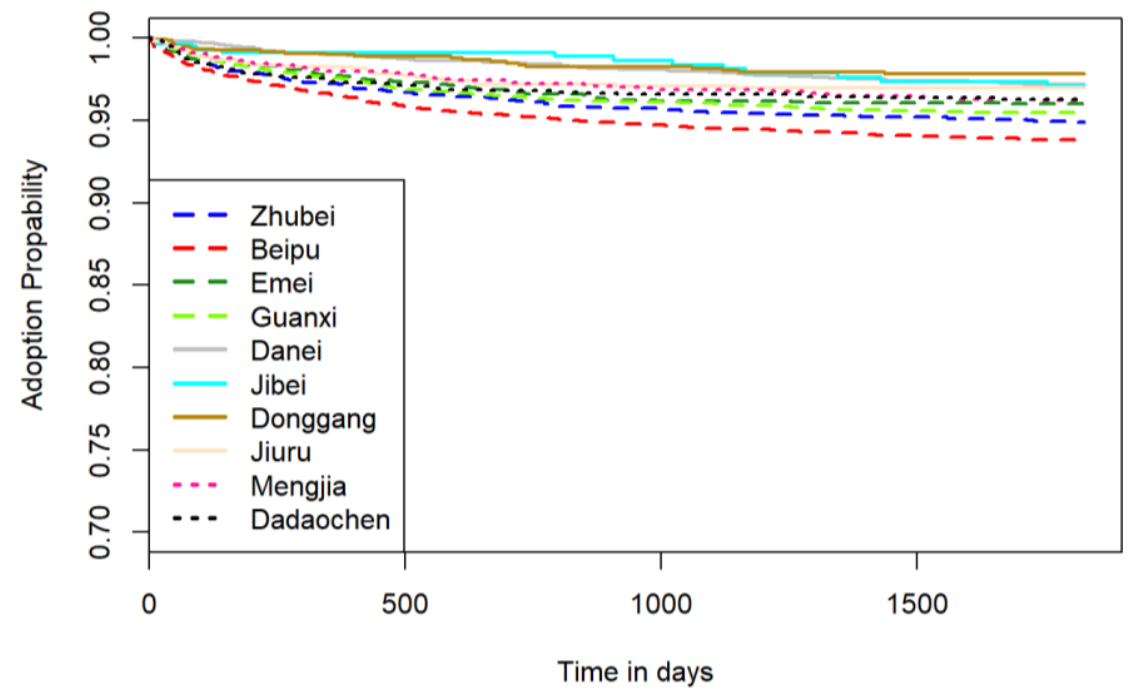

Figure 6: Kaplan-Meier curve for each region for girls in Taiwan, 1906-1940

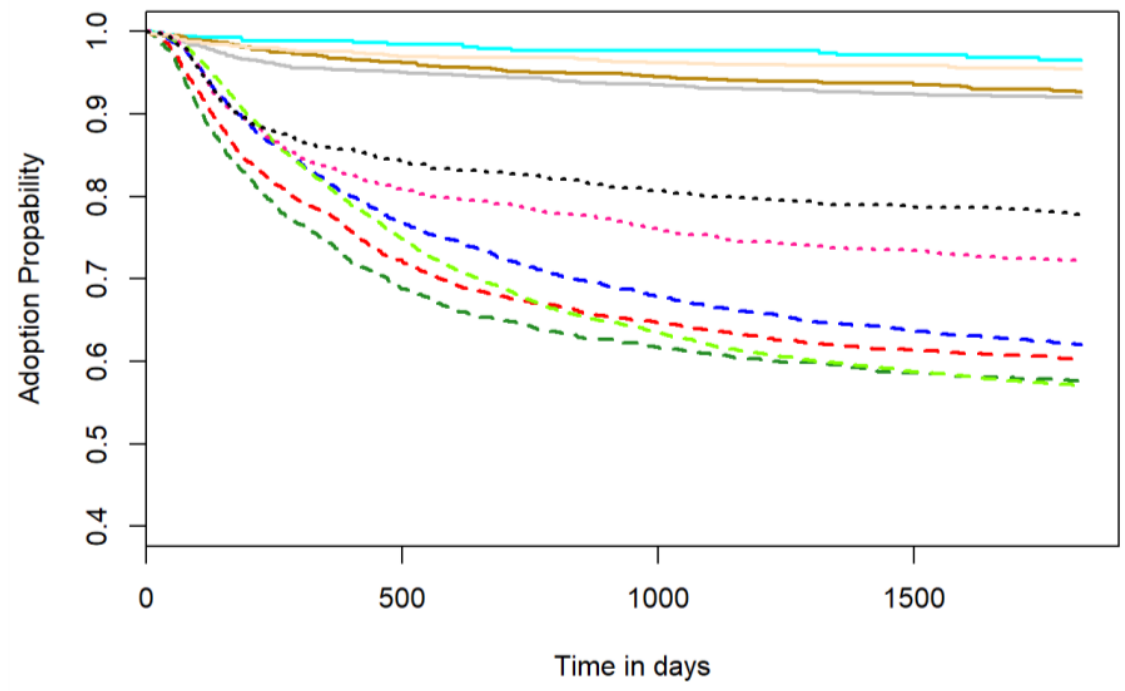

The first descriptive analyses already suggest that gender, same-sex sibling order and regional variation seem to have played a major role in influencing the adoption risks of children living in Taiwan during the Japanese colonial period. Boys were given away for adoption much less often in all regions, and when they were adopted out of the household it was almost never the first-born son. This demonstrates son preference and the key role they played in securing the family line. Many girls were given away for adoption, especially in northern Taiwan, and although studies always emphasise the uselessness of daughters, being a later-born daughter compared to a first-born one meant that adoption risks almost doubled. This indicates the importance of sibling order in Taiwanese life courses. In 
addition, these univariate analyses confirm the observations of earlier regional ethnographic and anthropological studies and suggest that these observations may also hold for our sample of the whole of Taiwan. Still, there might be confounding variables. Moreover, same-sex birth order at birth does not reflect reality in which the sibling composition and size may change over time. To be able to look in more detail, investigate more possible determinants for adoption, and take changing sibling composition into account, the next section investigates who is given away for adoption in multivariate Cox proportional hazard models, with time-varying variables.

\subsection{Multivariate results}

The main goal of this study is to investigate what factors determined whether children were given away for adoption, while taking into account gender, same-sex birth order, presence of adopted sisters, adopted brothers, grandparents, and other possible influencing factors. The results from the Cox proportional hazard models for Taiwan, southern Taiwan, northern Taiwan, and Taipei are presented in Table 2. By doing so it is possible to not only investigate the determinants for giving away boys and girls separately for Taiwan, but also to observe whether there are important differences between urban northern Taiwan, rural northern Taiwan and rural southern Taiwan. It should, however, be noted that because adoption was less frequent in southern Taiwan, and for Taipei the number of observations is more limited, the results of these regions may not be statistically significant because of the lower number of adoptions taking place.

Overall, the factors increasing or decreasing the risks of adoption are similar in all regions, although determinants are not always statistically significant. For boys, same-sex birth order, the presence of grandparents, the socio-economic status of the head of the household, the region, time period, and being an illegitimate child were key for lower or higher risks of being adopted out of the family in Taiwan. Yet only two factors were statistically significant in all regions: same-sex birth order increased adoption risks and the presence of a grandfather decreased adoption risks. The higher risk of being adopted out of the household when a boy is of a higher same-sex birth order demonstrates the importance of the presence of older brothers for the decision to adopt out a son. It also confirms the univariate results that a couple would almost never adopt out a first-born son as he would become the one to continue the family lineage. The observation that the presence of grandparents, in particular the grandfather, decreases the adoption risks demonstrates the parental power of the senior generation in the household and the fact that giving away sons was often considered a last resort. In addition, from their perspective it might be considered more urgent to make sure that there were descendants who could perform the rituals before they themselves joined the ancestors. The same argument can be made for illegitimate sons who were often not needed to continue the family line - and if they were needed, they would be acknowledged by the father - which may explain their higher risks of adoption. The varying results of the occupation of the head of the household demonstrate that sons of households of which the 
head had a lower socio-economic status had higher risks of being adopted out of the family. The fact that in particular households with a low socio-economic status gave away sons more and others did not may be caused by the fact that households could receive financial compensation for giving away their sons for adoption.

Table 2: Cox proportional hazards models for male and female adoption risks (0-5 years) in Taiwan, 1906-1940

\begin{tabular}{|c|c|c|c|c|c|c|c|c|}
\hline & \multicolumn{4}{|c|}{ Boys } & \multicolumn{4}{|c|}{ Girls } \\
\hline & Taiwan & Northern & Southern & Taipei & Taiwan & Northern & Southern & Taipei \\
\hline Same-sex birth order & $2.973^{* * * *}$ & $3.113 * * *$ & $2.505 * * *$ & $2.862 * * *$ & $1.366^{* * * *}$ & $1.312 * * *$ & $1.731 * * *$ & $1.577 * * * *$ \\
\hline $\begin{array}{l}\text { Adopted sister } \\
\text { No } \\
\text { Yes }\end{array}$ & $\begin{array}{l}\text { Ref. } \\
1.029 \\
\end{array}$ & $\begin{array}{l}\text { Ref. } \\
1.027\end{array}$ & $\begin{array}{l}\text { Ref. } \\
1.202\end{array}$ & $\begin{array}{l}\text { Ref. } \\
0.896\end{array}$ & $\begin{array}{l}\text { Ref. } \\
1.444 * * *\end{array}$ & $\begin{array}{l}\text { Ref. } \\
1.436^{* * *}\end{array}$ & $\begin{array}{l}\text { Ref. } \\
1.422\end{array}$ & $\begin{array}{l}\text { Ref. } \\
1.531^{* * * *}\end{array}$ \\
\hline $\begin{array}{l}\text { Adopted brother } \\
\text { No } \\
\text { Yes }\end{array}$ & $\begin{array}{l}\text { Ref. } \\
0.772\end{array}$ & $\begin{array}{l}\text { Ref. } \\
0.736\end{array}$ & $\begin{array}{l}\text { Ref. } \\
0.355\end{array}$ & $\begin{array}{l}\text { Ref. } \\
1.063\end{array}$ & $\begin{array}{l}\text { Ref. } \\
1.213 * *\end{array}$ & $\begin{array}{l}\text { Ref. } \\
1.286^{* * *}\end{array}$ & $\begin{array}{l}\text { Ref. } \\
0.478\end{array}$ & $\begin{array}{l}\text { Ref. } \\
0.969\end{array}$ \\
\hline $\begin{array}{l}\text { Grandmother } \\
\text { No } \\
\text { Yes } \\
\end{array}$ & $\begin{array}{l}\text { Ref. } \\
0.781 * *\end{array}$ & $\begin{array}{l}\text { Ref. } \\
0.842 \\
\end{array}$ & $\begin{array}{l}\text { Ref. } \\
0.530^{* *}\end{array}$ & $\begin{array}{l}\text { Ref. } \\
0.679 \\
\end{array}$ & $\begin{array}{l}\text { Ref. } \\
0.916^{* *}\end{array}$ & $\begin{array}{l}\text { Ref. } \\
0.914^{* *}\end{array}$ & $\begin{array}{l}\text { Ref. } \\
0.883\end{array}$ & $\begin{array}{l}\text { Ref. } \\
0.988 \\
\end{array}$ \\
\hline $\begin{array}{l}\text { Grandfather } \\
\text { No } \\
\text { Yes } \\
\end{array}$ & $\begin{array}{l}\text { Ref. } \\
0.511^{* * *}\end{array}$ & $\begin{array}{l}\text { Ref. } \\
0.499 * * *\end{array}$ & $\begin{array}{l}\text { Ref. } \\
0.580\end{array}$ & $\begin{array}{l}\text { Ref. } \\
0.507\end{array}$ & $\begin{array}{l}\text { Ref. } \\
0.965\end{array}$ & $\begin{array}{l}\text { Ref. } \\
0.964\end{array}$ & $\begin{array}{l}\text { Ref. } \\
0.943\end{array}$ & $\begin{array}{l}\text { Ref. } \\
0.931\end{array}$ \\
\hline $\begin{array}{l}\text { Occupation head } \\
\text { Farmers } \\
\text { Low SES } \\
\text { High SES } \\
\text { Unknown } \\
\end{array}$ & $\begin{array}{l}\text { Ref. } \\
1.234^{*} \\
0.797^{*} \\
0.505^{* *} \\
\end{array}$ & $\begin{array}{l}\text { Ref. } \\
1.442 * * * \\
1.061 \\
0.508 * * \\
\end{array}$ & $\begin{array}{l}\text { Ref. } \\
0.632 \\
0.657 \\
0.467 \\
\end{array}$ & $\begin{array}{l}\text { Ref. } \\
1.225 \\
0.684 \\
\text { NA } \\
\end{array}$ & $\begin{array}{l}\text { Ref. } \\
0.735^{* * * *} \\
0.643^{* * *} \\
0.705^{* * *} \\
\end{array}$ & $\begin{array}{l}\text { Ref. } \\
0.776 * * * \\
0.630 * * * \\
0.654\end{array}$ & $\begin{array}{l}\text { Ref. } \\
0.917 \\
0.985 \\
1.023 \\
\end{array}$ & $\begin{array}{l}\text { Ref. } \\
0.591 * \\
0.559 * \\
\text { NA }\end{array}$ \\
\hline $\begin{array}{l}\text { Ethnicity } \\
\text { Hokkien } \\
\text { Hakka } \\
\text { Other } \\
\end{array}$ & $\begin{array}{l}\text { Ref. } \\
1.232 * \\
0.908 \\
\end{array}$ & $\begin{array}{l}\text { Ref. } \\
1.085 \\
0.885\end{array}$ & $\begin{array}{l}\text { Ref. } \\
0.001 * * * \\
0.704\end{array}$ & $\begin{array}{l}\text { Ref. } \\
0.001 * * * \\
0.955 \\
\end{array}$ & $\begin{array}{l}\text { Ref. } \\
1.081 * \\
0.561 * * * \\
\end{array}$ & $\begin{array}{l}\text { Ref. } \\
1.068 \\
0.615^{* * *} \\
\end{array}$ & $\begin{array}{l}\text { Ref. } \\
0.302 \\
0.349^{* * *}\end{array}$ & $\begin{array}{l}\text { Ref. } \\
3.725 * * * \\
0.195 * * *\end{array}$ \\
\hline $\begin{array}{l}\text { Marriage type parents } \\
\text { Major } \\
\text { Minor } \\
\text { Uxorilocal } \\
\text { Other }\end{array}$ & $\begin{array}{l}\text { Ref. } \\
1.100 \\
1.168 \\
0.947\end{array}$ & $\begin{array}{l}\text { Ref. } \\
1.068 \\
1.035 \\
0.780\end{array}$ & $\begin{array}{l}\text { Ref. } \\
0.825 \\
1.742^{*} \\
1.091\end{array}$ & $\begin{array}{l}\text { Ref. } \\
1.193 \\
1.178 \\
1.848\end{array}$ & $\begin{array}{l}\text { Ref. } \\
1.124 * * * \\
0.940 \\
0.991\end{array}$ & $\begin{array}{l}\text { Ref. } \\
1.135 * * * \\
0.907 \\
0.986\end{array}$ & $\begin{array}{l}\text { Ref. } \\
0.765 \\
1.066 \\
0.886\end{array}$ & $\begin{array}{l}\text { Ref. } \\
1.035 \\
1.136 \\
1.054\end{array}$ \\
\hline $\begin{array}{l}\text { Illegitimate } \\
\text { No } \\
\text { Yes }\end{array}$ & $\begin{array}{l}\text { Ref. } \\
2.172 * * * \\
\end{array}$ & $\begin{array}{l}\text { Ref. } \\
2.138^{* * * *}\end{array}$ & $\begin{array}{l}\text { Ref. } \\
3.149^{* *}\end{array}$ & $\begin{array}{l}\text { Ref. } \\
1.370 \\
\end{array}$ & $\begin{array}{l}\text { Ref. } \\
0.805^{* *}\end{array}$ & $\begin{array}{l}\text { Ref. } \\
0.818^{*}\end{array}$ & $\begin{array}{l}\text { Ref. } \\
0.953 \\
\end{array}$ & $\begin{array}{l}\text { Ref. } \\
0.817 \\
\end{array}$ \\
\hline $\begin{array}{l}\text { Previous child died } \\
\text { No } \\
\text { Yes }\end{array}$ & $\begin{array}{l}\text { Ref. } \\
1.051 \\
\end{array}$ & $\begin{array}{l}\text { Ref. } \\
1.072 \\
\end{array}$ & $\begin{array}{l}\text { Ref. } \\
0.955 \\
\end{array}$ & $\begin{array}{l}\text { Ref. } \\
1.042 \\
\end{array}$ & $\begin{array}{l}\text { Ref. } \\
0.704 * * *\end{array}$ & $\begin{array}{l}\text { Ref. } \\
0.711^{* * * *}\end{array}$ & $\begin{array}{l}\text { Ref. } \\
0.617 * *\end{array}$ & $\begin{array}{l}\text { Ref. } \\
0.694 * *\end{array}$ \\
\hline $\begin{array}{l}\text { Period } \\
1906-1925 \\
1926-1940 \\
\end{array}$ & $\begin{array}{l}\text { Ref. } \\
0.807^{* *}\end{array}$ & $\begin{array}{l}\text { Ref. } \\
0.814 *\end{array}$ & $\begin{array}{l}\text { Ref. } \\
0.786 \\
\end{array}$ & $\begin{array}{l}\text { Ref. } \\
0.788\end{array}$ & $\begin{array}{l}\text { Ref. } \\
0.738^{* * * *}\end{array}$ & $\begin{array}{l}\text { Ref. } \\
0.764 * * *\end{array}$ & $\begin{array}{l}\text { Ref. } \\
0.603 * * *\end{array}$ & $\begin{array}{l}\text { Ref. } \\
0.621 * * *\end{array}$ \\
\hline $\begin{array}{l}\text { Region } \\
\text { North } \\
\text { South }\end{array}$ & $\begin{array}{l}\text { Ref. } \\
0.625^{* * * *}\end{array}$ & & & & $\begin{array}{l}\text { Ref. } \\
0.159^{* * *}\end{array}$ & & & \\
\hline
\end{tabular}

Signif. codes: '***' $0.0011^{\prime * *} 0.011^{\prime *} 0.05$.

There are only two statistically significant differences in the effects of adoption risks between the regions. The first is the lower risk of adoption of children with Hakka ethnicity in southern Taiwan and in Taipei. However, their number is too low to draw any conclusions. The second difference is that in southern Taiwan, when parents had an uxorilocal marriage, sons had statistically significant higher risks of being adopted out of the household. Uxorilocal marriages varied locally, but this finding could 
suggest that in places where this was more common the traditions around son preference and family continuity were less enforced as well. Moreover, it might suggest that in these uxorilocal households male labour was acquired by marrying men into the household instead of bearing sons. Still, the number of male adoptions is very low in southern Taiwan, so these conclusions may be very specific to some households. Lastly, in northern Taiwan the effect of birth order was stronger compared to the other regions, indicating that this played a more important role there.

For girls, the same-sex birth order, presence of an adopted sister, adopted brother, grandmother, the socio-economic status of the head of the household, whether a previous child died, region and time period were crucial for the risks of being adopted out of the family in Taiwan. The effect of the presence of an adopted brother, a grandmother, the marriage type of the parents, and being an illegitimate daughter were, however, not statistically significant in all regions, but only in northern Taiwan. Just as was the case for boys, the higher risk of being adopted out of the household when a girl is of a higher same-sex birth order demonstrates the importance of the presence of older sisters in making the decision to give away a daughter for adoption. It is also in line with the univariate results that demonstrate that couples would be more inclined to adopt out later-born daughters compared to first-born daughters. It reflects the idea that daughters also have a (gendered) function within the household. This argument is reinforced by the increased risks of adoption when an adopted sister is present, who may take over many of the necessary roles daughters fulfil in the household. In addition, these findings also demonstrate the importance of circulating children, especially girls, as higher risks of being given out for adoption at later birth ranks or when an adopted sister or brother is present suggests that households opted to give away their daughters more frequently. The main reason for doing so could be that too many daughters increased the dilution of resources which could be better used for more useful and permanent household members. As it was mostly the Chinese ethnic groups Hakka and Hokkien which employed little daughter-in-law adoption, this explains why being of another ethnicity means having lower risks of being given away for adoption. Lastly, earlier studies have already demonstrated that from the 1930s onwards girl adoption becomes less common because of a declining trend in little daughter-in-law adoptions. This is also confirmed by the lower adoption risks after 1925 for girls.

In contrast to the motivation given by anthropological studies, having a grandmother present actually decreased the risk of being given away for adoption for girls. This is somewhat surprising as it is often argued that it was not the mother, but the mother's mother-in-law, who determined who was given away for adoption, which should result in more children being adopted out than when mothers made this choice themselves. The fact that the opposite result was found might, however, be explained by the positive role the paternal grandmother could play in raising her grandchildren. Women without a grandmother present might feel the pressure to give away their daughters more often in order to be able to take better care of, and pay more attention to, their sons, older daughters or adopted daughters. This would be in line with the observations of anthropologists that mothers would avoid raising several young 
children at once and therefore preferred to give a child away. The varying results of the occupation of the head of the household demonstrate that in contrast to all other socio-economic groups, daughters of households of which the head was a farmer had significantly higher risks of being adopted out of the family. In particular, farmers in northern Taiwan can be considered poor and had limited resources to raise their children, which led to higher risks of adoption because households would prefer sons. In contrast, higher socio-economic groups had lower risks of girls being given away for adoption. This might on the one hand be explained by the fact that daughters could be used to form alliances between families through a major marriage and that when sufficient resources were available some households may simply choose to raise their own daughters.

There are four statistically significant differences in the effects of adoption risks between the regions for girls. The first is that the Hakka ethnicity has much higher adoption risks compared to Hokkien. There is no clear motivation for this result. The marriage type for parents is worth elaborating on, as it may offer some clues to regional differences in motivation for adoption. In northern Taiwan, when parents had a minor marriage, daughters had statistically significant higher risks of being given away for adoption compared to daughters of parents who had a major marriage. This may suggest that, next to region being an important determinant of the regional cultural and economic norms for little daughter-in-law adoption, on a more individual level minor marriages may also have had an effect. Third, in southern Taiwan socio-economic status is not important for adoption risks, which may be a result of daughters being more important in agricultural tasks compared to northern Taiwan (Pasternak 1983). One last difference in the size of the effect is the variation in the influence of same-sex birth order on adoption risks in northern and southern Taiwan. As hypothesised, the effect in southern Taiwan is stronger, possibly because adoption was less common and therefore having more older sisters present in the household caused parents to choose to give away a daughter for adoption.

To further investigate household decision-making for giving away children on the basis of a particular sibship composition, this is tested by looking at the adoption risks if non-adopted or adopted brothers and sisters are present in several age categories. The results from the Cox proportional hazard models for Taiwan are presented in Table 3. For boys only the number of older brothers increased the risks of being given away for adoption. The number of sisters decreased the risk of adoption. This might be an indicator that the family was able to support their daughters in contrast to households without any daughters present. For girls, the results demonstrate that having a brother in any age category in the household compared to having none increased adoption risks. The same is true for having sisters and adopted sisters, although having sisters or adopted sisters aged 10 or older did not increase adoption risks to a statistically significant extent. Having adopted brothers only increased adoption risks when they were younger or between zero and five years older. The adoption risks for when younger adopted sisters were present are especially striking, which confirms again the exchange of daughters for little daughters-in-law. In general these findings suggest that not only birth position among same-sex siblings, 
but also the age and adoption status of siblings, matters for adoption risks. Adoption risks are highest when having siblings that are younger or between zero and five years older. In other words, when there were more siblings of a similar age, it increased adoption risks most for girls, but not for boys. These findings suggest that household decision-making also depended upon how many children were actually present in the household.

Table 3: Cox proportional hazards models for female adoption risks (0-5 years) in Taiwan, 1906-1940

\begin{tabular}{|l|l|l|}
\hline \multicolumn{1}{|c|}{ Boys } & \multicolumn{1}{|c|}{ Girls } \\
\hline $\begin{array}{l}\text { Brothers 10+ older } \\
\text { No } \\
\text { Yes }\end{array}$ & Ref. & Ref. \\
\hline Brothers 5-10 older & $2.331^{* * *}$ & $1.099^{* *}$ \\
No & & \\
Yes & Ref. & Ref. \\
\hline Brothers 0-5 older & $1.671^{* * *}$ & $1.305^{* * *}$ \\
No & & \\
Yes & Ref. & Ref. \\
\hline Brothers younger & $1.830^{* * *}$ & $1.776^{* * *}$ \\
No & & \\
Yes & Ref. & Ref. \\
\hline Sisters 10+ older & 0.960 & $1.595^{* * *}$ \\
No & & \\
Yes & Ref. & Ref. \\
\hline Sisters 5-10 older & $0.668 * * *$ & 1.029 \\
No & & \\
Yes & Ref. & Ref. \\
\hline Sisters 0-5 older & $0.608 * * *$ & $1.361^{* * *}$ \\
No & & \\
Yes & Ref. & Ref. \\
\hline Sisters younger & $0.584 * * *$ & $1.700^{* * *}$ \\
\hline No & & \\
Yes & Ref. & Ref. \\
\hline Adopted Sisters 10+ older & 0.808 & $1.319^{* * *}$ \\
No & & \\
Yes & Ref. & Ref. \\
\hline Adopted Sisters 5-10 older & 0.859 & 0.934 \\
No & Ref. & Ref. \\
Yes & 1.086 & $1.087 *$ \\
\hline Adopted Sisters 0-5 older & & \\
No & Ref. & Ref. \\
Yes & 1.043 & $1.632^{* * *}$ \\
\hline Adopted Sisters younger & & \\
No & Ref. & Ref. \\
Yes & 1.477 & $6.842^{* * *}$ \\
\hline Adopted Brothers 10+ older & & \\
No & Ref. \\
Yes & 0.693 & 1.108 \\
\hline Adopted Brothers 5-10 older & & \\
No & & \\
Yes & & \\
\hline Adopted Brothers 0-5 older & & \\
\hline
\end{tabular}




\begin{tabular}{|l|l|l|}
\hline No & Ref. & Ref. \\
Yes & 0.604 & $1.764^{* * *}$ \\
\hline Adopted Brothers younger & & \\
No & Ref. & Ref. \\
Yes & 4.550 & $4.463^{* * *}$ \\
\hline
\end{tabular}

Same control variables are used as in Table 2, but not shown here. Signif. codes: '***' $0.0011^{\prime * *} 0.01$ '*' 0.05 .

\section{Discussion and Conclusion}

As was the case in most of East Asia, adoption was part of a family strategy to secure descent and the lineage in Taiwan as well. While most studies have focused on the receiving end of these adoption practices - the family into which sons and daughters were adopted - the aim of this study is to focus on who was given away for adoption out of the household. By doing so, the perspective is changed, in order to investigate adoption not as a strategy to continue the family line, but to as a strategy for dealing with excess children among the household whose successorship is already assured. Taiwan is particularly interesting as both sons and daughters are adopted out of the household. Furthermore, by analysing reliable and continuous data from a wide variety of research sites, this study goes one step further than previous studies to see whether the enormous differences in adoption rates between rural southern, rural northern and urban northern Taiwan also caused differences in the determinants for giving away sons and daughter for adoption and to test new hypotheses about the causes of adoption.

In general, the analyses confirm the overall importance of gender, same-sex birth order and variation over time and place in influencing adoption risks for children in Taiwan during the period 1906-1940 as previous literature has argued. Girls have much higher adoption risks compared to boys, but for both sexes children who have older siblings of the same sex present in the household have higher risks of adoption. It confirms the importance of having at least one child to ensure the continuation of the family line. Having a boy was in that sense essential, but daughters could also be used to achieve this goal. Moreover, the importance of ensuring a future wife resulted in giving away daughters when a little daughter-in-law had already been adopted into the family. A new finding is the importance of grandparents in lowering the risks of adoption, which points to the importance of particular family members in household decision-making regarding adoption. Next to these results, this study confirms the importance of socio-economic status, illegitimacy and the death of a previous child for adoption risks. For instance, farmers who needed labour for work on the fields would be less inclined to give away a son compared to lower socio-economic groups, but were much more motivated to give away their daughters, which is in line with existing son preferences. ${ }^{11}$ Lastly, the effect of sibling composition

\footnotetext{
${ }^{11}$ Wolf and Huang (1980) argued that not only lower socio-economic status groups adopted little daughters-inlaw and that therefore this could not be the explanatory factor behind household adoption of girls. However, the present study shows that, when it comes to being adopted out of the household, socio-economic status does matter.
} 
for the adoption risks of girls showed that we should include ideas about household decision-making and the division of tangible and intangible resources to a greater degree, as the presence of similar age or younger siblings of either sex increased the adoption risks greatly for girls.

In summary, we demonstrated that it is important to pay greater attention to the reasons and motivation of households for giving away children for adoption, relative to the reasons for adopting children into the household. It provides a broader perspective on adoption practices and how children were circulated to households with too many or too few and how this benefitted both kinds. Future studies should incorporate these findings, but above all they should go beyond studying adoption as a static event. In the case of Taiwan, adoptions were cancelled in some cases and children were sent back to their natal households, while in other cases adopted children were given away for adoption again. This demonstrates that the processes and practices of adoption are dynamic and can therefore be more complex than current studies demonstrate. Moreover, as the effect of grandparents and sibling composition on adoption risks demonstrated, by more fully including specific kin in a household it may offer some suggestions as to how these family dynamics work in family decision-making. It may show how kin can support or compete and exert social influence. One could argue, for instance, that the way kin influences adoption risks may differ for social groups within regions, concerning which this study could not say more due to the limitations of the current data. The same might also be true for families in which minor or uxorilocal marriage is more common, as some results in this study have indicated. Lastly, we think some answers to these remaining questions could be obtained by looking more closely at the household, family members and individual life courses of boys and girls given away for adoption.

Acknowledgements: The sources of Japanese household registers in Taiwan used in this paper are partly collected by: Hsiang-Shui Chen (Jiuru), Paul Katz (Donggang), Ying-Chang Chuang (Zhubei \& Emei), Arthur P. Wolf and Hill Gates (Mengjia and Taodaocheng). These registers were digitised as the "Taiwan Historical Household Registers Database, 1906-1945" (THHRD) by the Program of Historical Demography, Research Center for Humanities and Social Sciences, Academia Sinica, and contributed to this paper. Members of the Radboud Group for Historical Demography and Family History at Radboud University and members of the Program of Historical Demography at Academia Sinica provided valuable comments. We are especially grateful to Yulin Huang for his help with the database, and to Yinghui Hsieh, Ying-Chang Chuang and Wen-Shan Yang for their support. Theo Engelen and Hilde Bras in particular helped to improve this paper by providing key suggestions. Arthur P. Wolf and Hill Gates should also be mentioned as they inspired us to undertake this research. This work was supported by The Netherlands Organisation for Scientific Research (NWO) Graduate Programme under Grant [022.002.003] and the Neys-Van Hoogstraten Foundation under Grant [TW266]. 


\section{References}

Barclay, George W. 1954. Colonial Development and Population in Taiwan. Princeton, New Jersey: Princeton University Press.

Barrett, Richard E. 1980. "Short-Term Trends in Bastardy in Taiwan.” Journal of Family History 5(3):293-312.

Chen, Fu-Jen. 2016. “Maternal Voices in Personal Narratives of Adoption.” Women's Studies 45(2):162-87. Retrieved (http://dx.doi.org/10.1080/00497878.2015.1122504).

Chen, Yuyu et al. 2015. "Girl Adoption in China-A Less-Known Side of Son Preference.” Population Studies 69(2):161-78. Retrieved March 31, 2015 (http://dx.doi.org/10.1080/00324728.2015.1009253).

Chu, C. Y.Cyrus and Ruoh-Rong Yu. 2010. Understanding Chinese Families: A Comparative Study of Taiwan and Southeast China. Oxford University Press.

Chuang, Ying-chang and Arthur P. Wolf. 1995. "Marriage in Taiwan, An Example of Regional Diversity." The Journal of Asian Studies 54(3):781-95.

Cohen, Myron L. 1976. House United, House Divided: The Chinese Family in Taiwan. Columbia University Press New York.

Diamond, Norma. 1969. K'un Shen: A Taiwan Village. New York: Holt, Rinehart and Winston Inc.

Engelen, Theo and Ying-Hui Hsieh. 2007. Two Cities, One Life: Marriage and Fertility in Lugang and Nijmegen. Amsterdam: Aksant.

Fauve-Chamoux, Antoinette. 1998. "Introduction: Adoption, Affiliation, and Family Recomposition-inventing Family Continuity." The History of the Family 3(4):385-92. Retrieved (http://www.sciencedirect.com/science/article/pii/S1081602X9980253X).

Fauve-Chamoux, Antoinette. 2005. "A Comparative Study of Family Transmission Systems in the Central Pyrenees and Northeastern Japan.” History of the Family 10(3):231-48.

Feng, Wang and James Lee. 1998. "Adoption among the Qing Nobility and Its Implications for Chinese Demographic Behavior." History of the Family 3(4):411-27.

Fricke, Tom, J. S. Chang, and L. S. Yang. 1994. "Historical and Ethnographic Perspectives on the Chinese Family." Pp. 22-48 in Social change and the family in Taiwan. Chicago \& London: The University of Chicago Press.

Gates, Hill, Jan Kok, and Sping Wang. 2006. "Burden or Opportunity? Illegitimate Births in the Netherlands and Taiwan.” Pp. 81-104 in Positive or preventive. Reproduction in Taiwan and the Netherlands, 1850-1940., edited by Y.-C. Chuang, T. Engelen, and A. P. Wolf. Amsterdam: Aksant.

Goody, Jack. 1969. "Adoption in Cross-Cultural Perspective Adoption in Cross-Cultural Perspective.” Comparative Studies in Society and History 11(1):55-78.

Greenhalgh, Susan and Jiali Li. 1995. "Engendering Reproductive Policy and Practice in Peasant China: For a 
Feminist Demography of Reproduction.” Signs: Journal of Women in Culture and Society 20(3):601-41. Retrieved (http://www.journals.uchicago.edu/doi/10.1086/495002).

Hanley, Susan. 1985. "Family and Fertility in Four Tokugawa Villages.” Pp. 196-228 in Family and population in East Asian history, edited by S. Hanley and A. P. Wolf. Stanford: Stanford University Press.

Hekster, Olivier. 2014. "Son of Two Fathers? Trajan and the Adoption of Emperorship in the Roman Empire." History of the Family 19(3):380-92.

Johansson, Sten and Ola Nygren. 1991. "The Missing Girls of China: A New Demographic Account." Population and Development Review 17(1):35-51.

Johnson, Kay, Banghan Huang, and Liyao Wang. 1998. "Infant Abandonment and Adoption in China." Population and Development Review 24(3):469-510.

Kim, Kuentae and Hyunjoon Park. 2010. "Family Succession through Adoption in the Chosun Dynasty." History of the Family 15(4):443-52. Retrieved (http://dx.doi.org/10.1016/j.hisfam.2010.09.002).

King, Michelle T. 2014. Between Birth and Death: Female Infanticide in Nineteenth-Century China. Stanford: Stanford University Press. Retrieved July 24, 2015 (https://scholar.google.nl/scholar?as_ylo=2014\&q=michelle+king+infanticide\&hl=nl\&as_sdt=0,5\#0).

Kok, Jan. 2010. “Women's Agency in Historical Family Systems.” Pp. 10-50 in Agency, Gender and Economic Development in the World Economy 1850-2000 Testing the Sen Hypothesis, edited by J. L. Van Zanden, A. Rijpma, and J. Kok. London: Routledge.

Kurosu, Satom and Emiko Ochiai. 1995. "Adoption as an Heirship Strategy under Demographic Constraints: A Case from Nineteenth-Century Japan.” Journal of Family History 20(3):261-88.

Kurosu, Satomi. 1998. "Long Way to Headship, Short Way to Retirement: Adopted Sons in a Northeastern Village in Pre-Industrial Japan." History of the Family 3(4):393-410.

Kurosu, Satomi. 2010. "Reproduction in East Asian Historical Demography: Introduction.” History of the Family 15(4):365-69. Retrieved (http://dx.doi.org/10.1016/j.hisfam.2010.10.004).

Lee, James Z. and Wang Feng. 1999. One Quarter of Humanity: Malthusian Mythology and Chinese Realities, 1700-2000. Cambridge \& Londen: Harvard University Press.

Li, Chun-hao, Martin Kolk, Wen-shan Yang, and Ying-chang Chuang. 2019. "Uxorilocal Marriage as a Strategy for Heirship in a Patrilineal Society: Evidence from Household Registers in Early 20th-Century Taiwan Uxorilocal Marriage as a Strategy for Heirship in a." Stockholm Research Reports in Demography.

Lin, X. C. C. C., W. S. Yang, and Y. C. Chuang. 2014. “Another Marriage Choice: A Study of Uxorilocal Marriage in Taiwan, Comparative Research of Taipei (Urban) and Xinchu (Rural), 1906-1944.” Journal of Family History 39(4):388-403. Retrieved March 31, 2015 (http://jfh.sagepub.com/cgi/doi/10.1177/0363199014549146).

Lin, Xingchen. 2013. "Headship, Household Burden, and Infant Mortality in Taipei (1906-1944).” Journal of 
Family History 38(3):344-64. Retrieved March 31, 2015

(http://jfh.sagepub.com/cgi/doi/10.1177/0363199013484722).

Lindsay, Hugh. 2009. Adoption in the Roman World. Cambridge University Press.

Liu, Jihong, Ulla Larsen, and Grace Wyshak. 2004. "Factors Affecting Adoption in China, 1950-87.” Population Studies 58(1):21-36.

Liu, Shi-yung. 2004. “DIFFERENTIAL MORTALITY IN COLONIAL TAIWAN ( 1895-1945 ).” Annales de démographie historique 107:229-47.

Mattison, Siobhán M. et al. 2018. “Adopted Daughters and Adopted Daughters-in-Law in Taiwan : A Mortality Analysis Subject Category :" Royal Society Open Science 5(171745):1-15.

Mattison, Siobhán M., Melissa J. Brown, Bruce Floyd, and Marcus W. Feldman. 2015. “Adoption Does Not Increase the Risk of Mortality among Taiwanese Girls in a Longitudinal Analysis.” PloS one 10(4):1-18. Retrieved May 21, 2015

(http://www.pubmedcentral.nih.gov/articlerender.fcgi?artid=4414473\&tool=pmcentrez\&rendertype=abstra $\mathrm{ct})$.

Mungello, David E. 2008. Drowning Girls in China: Female Infanticide in China since 1650. New York: Rowman \& Littlefield Publishers.

Pasternak, Burton. 1983. Guests in the Dragon: Social Demography of a Chinese District 1895-1946. New York: Columbia University Press.

Riswick, Tim. 2013. “Gevangen Tussen Cultuur En Biologie. De Invloed van Gender En Adoptie Op Kindersterfte in de Taiwanese Familie in Hai-Shan, 1906-1945.” Pp. 71-102 in Gender in/en historische demografie. Historisch-demografisch onderzoek in Vlaanderen en Nederland, edited by K. Matthijs, P. Puschmann, H. Bras, and A. Janssens. Leuven: Acco.

Santos, Goncalo and Stevan Harrell, eds. 2017. Transforming Patriarchy. Chinese Families in the Twenty-First Century. Seattle \& London: University of Washington Press.

Saso, Michael R. 1999. Velvet Bonds: The Chinese Family. Carmel: New Life Center.

Sear, R. and R. Mace. 2008. "Who Keeps Children Alive? A Review of the Effects of Kin on Child Survival." Evolution and Human Behavior 29(1):1-18. Retrieved August 6, 2014 (http://linkinghub.elsevier.com/retrieve/pii/S1090513807001055).

Shepherd, John Robert et al. 2006. "Group Identity and Fertility : An Evaluation of the Role of Religion and Ethnicity in the Netherlands and Taiwan.” Pp. 121-62 in Positive or preventive? Reproduction in Taiwan and the Netherlands 1850-1940, edited by Y.-C. Chuang, T. Engelen, and A. P. Wolf. Amsterdam: Aksant.

Shi, Lihong. 2017. Choosing Daughters: Family Change in Rural China. Stanford: Stanford University Press.

Thornton, Arland and Hui-Sheng Lin. 1994. Social Change and the Family in Taiwan. Chicago \& London: University of Chicago Press. 
Wolf, Arthur P. 1968. “Adopt a Daughter-in-Law, Marry a Sister: A Chinese Solution to the Problem of the Incest Taboo.” American Anthropologist 70(5):864-74.

Wolf, Arthur P. 1995. Sexual Attraction and Childhood Association: A Chinese Brieffor Edward Westermarck. Stanford: Stanford University Press.

Wolf, Arthur P. 2005. "Europe and China: Two Kinds of Patriarchy.” Pp. 215-40 in Marriage and the family in Eurasia. Perspectives on the Hajnal hypothesis, edited by T. L. Engelen and A. P. Wolf. Amsterdam: Aksant.

Wolf, Arthur P. and Chieh-shan Huang. 1980. Marriage and Adoption in China: 1845-1945. Stanford University Press.

Wolf, Margery. 1968. The House of Lim: A Study of a Chinese Farm Family. New York: Appleton-CenturyCrofts.

Wolf, Margery. 1972. Women and the Family in Rural Taiwan. Stanford: Stanford University Press.

Xue, Xinran. 2011. Message from an Unknown Chinese Mother: Stories of Loss and Love. London: Vintage Publishing.

Yu, Guang-hong, Yu-lin Huang, and Ling-in Chuu. 2011. "Illegitimacy, Adoption, and Mortality among Girls in Penghu, 1906-1945.” Pp. 317-48 in Death at the Opposite Ends of the Eurasian Continent: Mortality Trends in Taiwan and the Netherlands, 1850-1945, edited by T. Engelen, J. R. Shepherd, Y. Wen-Shan, and W.-S. Yang. Amsterdam: Aksant.

Zhang, Weiguo. 2006a. “Child Adoption in Contemporary Rural China.” Journal of Family Issues 27(3):301-40.

Zhang, Weiguo. 2006b. "Who Adopts Girls and Why? Domestic Adoption of Female Children in Contemporary Rural China." The China Journal (56):63-82. Retrieved (http://search.ebscohost.com/login.aspx?direct=true \&db=aph\&AN=22198567\&site=ehost-live).

Zhang, Weiguo. 2008. "State, Gender and Uxorilocal Marriage in Contemporary Rural North China Press on Behalf of the College of Asia and the." The China Journal 60:111-32. 